\title{
No association between subclinical hypothyroidism and dyslipidemia in children and adolescents
}

\author{
Ashkan Habib ${ }^{1}$ and Asadollah Habib ${ }^{2 *}$
}

\begin{abstract}
Background: There are controversies about the correlation between higher levels of thyroid stimulating hormone (TSH) and dyslipidemia in children. This study was designed to assess the relation between lipid profile components and TSH levels in children.

Method: This cross-sectional study was performed in a pediatric endocrinology growth assessment clinic in Shiraz, southern Iran. Children aged 2-18 years who referred to the clinic from January until April 2018 were included. TSH levels equal or above $5 \mathrm{mIU} / \mathrm{L}$ and lower than $10 \mathrm{mIU} / \mathrm{L}$ with normal free T4 (FT4) were considered as having subclinical hypothyroidism (SH).

Results: Six hundred sixty-six children were euthyroid while 181 had SH. No significant difference was found between the mean serum total cholesterol $(P=0.713)$, LDL-C $(P=0.369)$, HDL-C $(P=0.211)$, non-HDL-C $(P=0.929)$, and triglyceride $(P=0.215)$ levels between euthyroid children and subjects with $\mathrm{SH}$. There was also no significant difference in the prevalence of dyslipidemias in any lipid profile components between the two groups. The adjusted correlation was not significant between TSH levels and any lipid profile component.

Conclusion: Based on the results of our study, we found no correlation between SH and dyslipidemia in children. The association between dyslipidemia and SH in children still seems to be inconsistent based on the results of this and previous studies. We recommend a meta-analysis or a significantly larger retrospective study on this subject.
\end{abstract}

Keywords: Lipid, Children, Thyroid, Hypothyroidism

\section{Introduction}

Subclinical hypothyroidism ( $\mathrm{SH})$ is defined as elevated thyroid stimulating hormone (TSH) levels, while T4 or free T4 (FT4) levels are normal [1]. It is a common disorder with a prevalence of $4-15 \%$ in the adult community $[2,3]$, while in the pediatric population, its prevalence is slightly lower than $2 \%[2,4]$.

Although initially symptom free, $2-5 \%$ of $\mathrm{SH}$ patient progress to overt hypothyroidism each year [5]. In

\footnotetext{
* Correspondence: habib1343@yahoo.com

${ }^{2}$ Department of Endocrinology, School of Medicine, Kazerun Branch, Islamic Azad University, PO Box: 71384-37984, First Floor, Zafar Building, Zand St, Shiraz, Iran

Full list of author information is available at the end of the article
}

addition, $\mathrm{SH}$ has been linked to several complications such as decreased cardiac output and higher chances of cardiac diseases [6-12], neuromuscular and neurobehavioral alterations, insulin resistance $[8,13-16]$ and specifically, obesity. Several studies have linked SH to higher BMI and BMI Z-scores [17-19], although weight reduction plans have resulted in normalization of TSH concentrations in some cases $[20,21]$.

Association of $\mathrm{SH}$ and dyslipidemia has been less clear cut. Studies have correlated SH in adults with higher levels of total cholesterol, low-density lipoprotein (LDL), non-high density lipoprotein (HDL), triglyceride (TG), and lower levels of HDL [22-24]. However, in a study

(c) The Author(s). 2020 Open Access This article is licensed under a Creative Commons Attribution 4.0 International License, which permits use, sharing, adaptation, distribution and reproduction in any medium or format, as long as you give appropriate credit to the original author(s) and the source, provide a link to the Creative Commons licence, and indicate if changes were made. The images or other third party material in this article are included in the article's Creative Commons licence, unless indicated otherwise in a credit line to the material. If material is not included in the article's Creative Commons licence and your intended use is not permitted by statutory regulation or exceeds the permitted use, you will need to obtain permission directly from the copyright holder. To view a copy of this licence, visit http://creativecommons.org/licenses/by/4.0/ The Creative Commons Public Domain Dedication waiver (http://creativecommons.org/publicdomain/zero/1.0/) applies to the data made available in this article, unless otherwise stated in a credit line to the data. 
by Meisinger and colleagues, only a higher TG level was correlated with higher levels of TSH in male participants. Higher levels of total cholesterol and LDL-C were only found in female participants [25].

In children however, reports about the correlation between the higher levels of TSH and dyslipidemia have been controversial. Some studies have shown higher levels of TC, LDL, and TG with an increase in TSH [2630]. Conversely, another study showed that only higher levels of TG was positively correlated with an increase in TSH level [31].

As there are controversies about the association of dyslipidemia and $\mathrm{SH}$ in children, we designed this crosssectional study to compare lipid profiles, including TG, total cholesterol, LDL-C, and HDL-C in children with $\mathrm{SH}$ compared with children with the euthyroid state.

\section{Method}

\section{Study design}

This was a cross-sectional study on children aged 2 to 18 years who referred to a pediatric endocrinology growth assessment clinic in the urban area of Shiraz city, southern Iran for routine growth follow-up from January until April 2018. The clinic is also a tertiary referral center where patients with other endocrine disorders are visited as well. Approximately eighty to ninety patients per day are visited in this center.

After obtaining informed consent from the parents, the children's blood samples were tested in a single laboratory for serum total cholesterol, LDL-C, HDL-C, Non-HDL-C, TG, TSH, and FT4 levels simultaneously in a non-fasting state. The non-fasting state was chosen as a result of high non-compliance and questionable compliance of the parents, especially in 2-4-year-old subjects, although it should be noted that fasting is generally not required for determination of a lipid profile [32]. The weight and height of the subjects were measured using Seca scale $(0.1 \mathrm{~kg}$ precision) and stadiometer $(0.1 \mathrm{~cm}$ precision), respectively, while they were lightly dressed and were asked to take off their shoes.

\section{Inclusion criteria}

For this study, inclusion criteria were: 1 - age of $2-18$ years; 2- the presence of normal free T4 $(0.8-1.8 \mathrm{ng} / \mathrm{dL})$; and 3- TSH level between 0.3 and $<10 \mathrm{mIU} / \mathrm{L}$ as recommended by the 2014 European Thyroid Association guideline on the management of $\mathrm{SH}$ in children [33].

\section{Exclusion criteria}

Exclusion criteria were 1- children who were on levothyroxine therapy at the time of assessment; 2- ongoing use of medications that might interfere with thyroid function test or lipid profile such as anti-thyroid medications, corticosteroids, and thiazides; 3 - children with familial hyperlipidemia; and 4- diseases that might affect lipid profile such as diabetes mellitus (DM), kidney disease, rheumatologic diseases, and other endocrine diseases.

\section{Anthropometric data}

847 children, including 366 (43.2\%) boys and 481 $(56.8 \%)$ girls, had the inclusion criteria and were selected for this study. For the precise calculation of body mass index (BMI), body mass index standard deviation score (BMI-SDS) and BMI percentile, UptoDate calculators, which are based on the growth charts of the Center for Disease Control (CDC), were used.

\section{Measurement of serum lipid profiles and thyroid functions}

Serum TSH and lipid profile were measured using Cobas e411 Analyzer (Mannheim, Germany) with electrochemiluminescence immunoassay (ECLIA) method and Dirui CS- T240 Auto chemistry Analyzer (Changchun, China) using Pars Azmoon kits (Iran), respectively. Assay performance was controlled using Elecsys PreciControl Universal for serum thyroid profile and TrueLab $\mathrm{N}$ and TruLab P for lipid profile. Auto Analyser was calibrated using Elecsys TSH CalSet and TruCal U. Interassay coefficients of variation (CVs) for TSH are 1.56\% for $1.37 \mathrm{mIU} / \mathrm{L}$ and $0.08 \%$ for $8.62 \mathrm{mIU} / \mathrm{L}$, respectively while inter and intra-assay CVs were $3.2 \mathrm{mg} / \mathrm{dL}$ and $2.29 \%$ for total cholesterol and $1.6 \mathrm{mg} / \mathrm{dL}$ and $1.49 \%$ for triglyceride, respectively. The study was approved by the Research Institutional Review Committee of Islamic Azad University, Kazerun branch (reference number: 1398.125).

\section{Cut-off levels}

Abnormal lipid profile cutoffs are based on the 2011 statement of the National Heart, Lung, and Blood Institute's (NHLBI) Expert Panel on Integrated Guidelines for Cardiovascular Health and Risk Reduction in Children and Adolescents and the 2008 American Academy of Pediatrics' (AAP) policy statement (Table 1) [34, 35].

TSH levels equal to or above $5 \mathrm{mIU} / \mathrm{L}$ were considered abnormal. All participants with high TSH levels were considered for a second measurement. For these participants, second TSH levels were considered for the study.

\section{Study analysis}

For analysis, the study group was divided into two age groups: 2-9 and 10-18 years, each representing before the start of puberty and after the start of puberty, respectively. Participants with TSH levels equal or above 5 $\mathrm{mIU} / \mathrm{L}$ and lower than $10 \mathrm{mIU} / \mathrm{L}$ with normal free T4 levels were categorized as having $\mathrm{SH}$. The relation between serum TSH and each lipid profile component 
Table 1 Definition of lipid levels in children from the 2011 Expert Panel Integrated Guidelines for Cardiovascular Health and Risk Reduction in Children and Adolescents

\begin{tabular}{llll}
\hline Category & $\begin{array}{l}\text { Acceptable } \\
\mathrm{mg} / \mathrm{dL}(\mathrm{mmol} / \mathrm{L})\end{array}$ & $\begin{array}{l}\text { Borderline } \\
\mathrm{mg} / \mathrm{dL}(\mathrm{mmol} / \mathrm{L})\end{array}$ & High \\
\hline TC & $<170(4.4)$ & 170 to $199(4.4$ to 5.2$)$ & $\geq 200(5.2)$ \\
LDL-C & $<110(2.8)$ & 110 to $129(2.8$ to 3.3$)$ & $\geq 130(3.4)$ \\
Non-HDL-C & $<120(3.1)$ & 120 to $144(3.1$ to 3.7$)$ & $\geq 145(3.8)$ \\
TG & & & \\
$\cdot$-0 to 9 years & $<75(0.8)$ & 75 to $99(0.8$ to 1.1$)$ & $\geq 100(1.1)$ \\
$\cdot$ 10 to 19 years & $<90(1 \mathrm{mmol} / \mathrm{L})$ & 90 to $129(1$ to 1.5$)$ & $\geq 130(1.5)$ \\
Category & Acceptable & Borderline & Low \\
HDL-C & $>45(1.2)$ & 40 to $45(1$ to 1.2$)$ & $<40(1)$ \\
\hline
\end{tabular}

Abbreviations: TC total cholesterol; LDL-C low-density lipoprotein cholesterol; $H D L-C$ high-density lipoprotein cholesterol; Non-HDL-C non-high-density lipoprotein cholesterol; $T G$ triglycerides

(dependent variable) was evaluated using partial variable correlation, adjusted for age, sex, and BMI Z-score. Comparisons were performed using Student $t$ test for continuous variables in Tables 2 and 3 and by Chi-square test for categorical variables in Tables 2 and 4 . A $P$ value $<0.05$ was considered statistically significant in all comparisons with a $95 \%$ confidence interval. All statistical analyses were performed using SPSS software version 25.0 (SPSS, Chicago, IL, USA).

\section{Results}

As shown in Table 2, of the 847 children in this study, 666 had TSH levels between 0.3 and $4.9 \mathrm{mIU} / \mathrm{L}$ who were considered as having euthyroid state while 181 children who had TSH levels of 5-9.9 mIU/L and were considered as having $\mathrm{SH}$. There was no statistically significant difference in the mean age of the participants with euthyroid and $\mathrm{SH}$ states $(9.96 \pm 3.40$ years vs. $9.98 \pm 3.28, P=0.945)$.

$42.8 \%$ of euthyroid children and $44.8 \%$ of the children with $\mathrm{SH}$ were male $(P=0.637)$. Overall, children with
$\mathrm{SH}$ had higher BMI Z-scores than euthyroid children $(P=0.012)$; as a result, this parameter had to be adjusted when calculating the correlation (Table 2).

Table 3 shows the mean levels of lipid profile components in euthyroid children and children with $\mathrm{SH}$ and the subgroups of 2-10 and 10-18 years of age. There was no statistically significant difference in any of the lipid profile components between euthyroid children and children with $\mathrm{SH}$ and in the subsequent age-related subgroups (Table 3).

Table 4 shows the prevalence of dyslipidemia, in each of the lipid profile components, in euthyroid children and children with $\mathrm{SH}$ and their respective age groups. Overall, there was no statistically significant difference in the prevalence of any of the lipid profile dyslipidemias between the euthyroid children and children with $\mathrm{SH}$ and in the subsequent agerelated subgroups (Table 4).

Table 5 shows the association between TSH levels and each of the lipid profile components based on the partial correlation method adjusted for age, sex, and BMI Z-score. No correlation was seen between TSH levels and any of the lipid profile components. The use of logistic regression was forgone due to the results of this study (Table 5).

\section{Discussion}

Relation of $\mathrm{SH}$ and dyslipidemia in children remains to be inconsistent as we found no correlation between TSH levels and lipid profile components. We also found no difference in the proportion of dyslipidemia and the mean serum lipid levels between euthyroid children and patients with $\mathrm{SH}$.

Most past studies on this subject have found some aspect of dyslipidemia pertaining to $\mathrm{SH}$ although the results have been conflicting. In a study by Unal $\mathrm{E}$ and colleagues on 38 children with $\mathrm{SH}$ compared with a control group, $\mathrm{SH}$ led to increased dyslipidemia (increased TC and LDL) [26] and likewise, in a study by Witte and co-workers, it

Table 2 Anthropometric characteristics of the study subjects

\begin{tabular}{|c|c|c|c|c|c|c|c|c|c|}
\hline & \multicolumn{2}{|l|}{ Total (847) } & \multirow[b]{2}{*}{$P$} & \multicolumn{2}{|c|}{ Age $2-10$ years (421) } & \multirow[b]{2}{*}{$P$} & \multicolumn{2}{|c|}{ Age $10-18$ years (426) } & \multirow[b]{2}{*}{$P$} \\
\hline & $\begin{array}{l}\text { Euthyroid } \\
(666)\end{array}$ & $\begin{array}{l}\text { Subclinical } \\
\text { Hypothyroid (181) }\end{array}$ & & $\begin{array}{l}\text { Euthyroid } \\
(325)\end{array}$ & $\begin{array}{l}\text { Subclinical } \\
\text { Hypothyroid (96) }\end{array}$ & & $\begin{array}{l}\text { Euthyroid } \\
(341)\end{array}$ & $\begin{array}{l}\text { Subclinical } \\
\text { Hypothyroid (85) }\end{array}$ & \\
\hline$\overline{\text { Age }}$ & $9.96 \pm 3.40$ & $9.98 \pm 3.28$ & 0.945 & $7.26 \pm 2.047$ & $7.54 \pm 1.79$ & 0.234 & $12.53 \pm 2.25$ & $12.74 \pm 2.21$ & 0.449 \\
\hline Sex (Male) & $42.8 \%$ & $44.8 \%$ & 0.637 & $34.8 \%$ & $39.6 \%$ & 0.388 & $50.4 \%$ & $50.6 \%$ & 0.980 \\
\hline Height (cm) & $135.20 \pm 19.48$ & $137.16 \pm 18.37$ & 0.226 & $121.17 \pm 15.60$ & $125.43 \pm 14.11$ & $0.017^{*}$ & $148.57 \pm 11.97$ & $150.40 \pm 12.79$ & 0.215 \\
\hline Weight (kg) & $38.66 \pm 20.22$ & $41.31 \pm 19.44$ & 0.116 & $26.99 \pm 12.23$ & $31.54 \pm 14.17$ & $0.002^{*}$ & $49.79 \pm 20.06$ & $52.34 \pm 18.72$ & 0.289 \\
\hline TSH (mIU/L) & $2.52 \pm 1.16$ & $6.90 \pm 1.52$ & $<0.001^{*}$ & $2.50 \pm 1.15$ & $6.80 \pm 1.51$ & $<0.001^{*}$ & $2.53 \pm 1.17$ & $7.01 \pm 1.52$ & $<0.001^{*}$ \\
\hline FT4 (ng/dL) & $1.40 \pm 0.25$ & $1.43 \pm 0.26$ & 0.242 & $1.39 \pm 0.25$ & $1.42 \pm 0.27$ & 0.298 & $1.42 \pm 0.25$ & $1.44 \pm 0.25$ & 0.491 \\
\hline BMI Z score & $0.16 \pm 1.84$ & $0.55 \pm 1.80$ & $0.012^{*}$ & $-0.08 \pm 1.92$ & $0.49 \pm 1.95$ & $0.011^{*}$ & $0.40 \pm 1.73$ & $0.62 \pm 1.62$ & 0.285 \\
\hline BMI & $19.76 \pm 6.14$ & $20.98 \pm 7.39$ & $0.024^{*}$ & $17.50 \pm 4.68$ & $19.19 \pm 5.44$ & $0.007^{*}$ & $21.91 \pm 6.57$ & $23.00 \pm 8.71$ & 0.205 \\
\hline
\end{tabular}


Table 3 Mean serum lipid profile components based on the subjects' thyroid status

\begin{tabular}{|c|c|c|c|c|c|c|c|c|c|}
\hline & \multicolumn{2}{|l|}{ Total (847) } & \multirow[b]{2}{*}{$P$} & \multicolumn{2}{|c|}{ Age 2-10 (421) } & \multirow[b]{2}{*}{$P$} & \multicolumn{2}{|c|}{ Age 10-18 (426) } & \multirow[b]{2}{*}{$P$} \\
\hline & $\begin{array}{l}\text { Euthyroid } \\
(666)\end{array}$ & $\begin{array}{l}\text { Subclinical } \\
\text { Hypothyroid (181) }\end{array}$ & & $\begin{array}{l}\text { Euthyroid } \\
\text { (325) }\end{array}$ & $\begin{array}{l}\text { Subclinical } \\
\text { Hypothyroid (96) }\end{array}$ & & $\begin{array}{l}\text { Euthyroid } \\
(341)\end{array}$ & $\begin{array}{l}\text { Subclinical } \\
\text { Hypothyroid (85) }\end{array}$ & \\
\hline $\mathrm{TC}(\mathrm{mg} / \mathrm{dL})$ & $\begin{array}{l}160.50 \pm \\
29.070\end{array}$ & $161.39 \pm 28.694$ & 0.713 & $\begin{array}{l}161.66 \pm \\
29.842\end{array}$ & $160.73 \pm 26.664$ & 0.782 & $\begin{array}{l}159.38 \pm \\
28.314\end{array}$ & $162.14 \pm 30.971$ & 0.431 \\
\hline LDL-c (mg/dL) & $\begin{array}{l}90.96 \pm \\
24.996\end{array}$ & $89.10 \pm 23.852$ & 0.369 & $\begin{array}{l}92.54 \pm \\
25.514\end{array}$ & $88.06 \pm 21.540$ & 0.119 & $\begin{array}{l}89.46 \pm \\
24.436\end{array}$ & $90.27 \pm 26.302$ & 0.788 \\
\hline $\mathrm{HDL}-\mathrm{c}(\mathrm{mg} / \mathrm{dL})$ & $\begin{array}{l}47.94 \pm \\
10.560\end{array}$ & $49.04 \pm 10.361$ & 0.211 & $\begin{array}{l}48.62 \pm \\
11.077\end{array}$ & $50.09 \pm 10.910$ & 0.253 & $\begin{array}{l}47.29 \pm \\
10.016\end{array}$ & $47.86 \pm 9.630$ & 0.637 \\
\hline $\begin{array}{l}\text { Non-HDL-c } \\
(\mathrm{mg} / \mathrm{dL})\end{array}$ & $\begin{array}{l}112.56 \pm \\
27.696\end{array}$ & $112.35 \pm 28.136$ & 0.929 & $\begin{array}{l}113.04 \pm \\
28.081\end{array}$ & $110.64 \pm 27.286$ & 0.459 & $\begin{array}{l}112.09 \pm \\
27.358\end{array}$ & $114.28 \pm 29.107$ & 0.515 \\
\hline TG (mg/dL) & $\begin{array}{l}104.98 \pm \\
54.934\end{array}$ & $113.83 \pm 91.342$ & 0.215 & $\begin{array}{l}97.18 \pm \\
48.897\end{array}$ & $114.95 \pm 104.861$ & 0.111 & $\begin{array}{l}112.40 \pm \\
59.251\end{array}$ & $112.56 \pm 73.757$ & 0.983 \\
\hline
\end{tabular}

Abbreviations: TC total cholesterol; $L D L-c$ low-density lipoprotein cholesterol; HDL-c high-density lipoprotein cholesterol; Non-HDL-c non-high-density lipoprotein cholesterol; $T G$ triglycerides

was shown that there was a significant positive association between TSH and all non-HDL parameters (total cholesterol, LDL-C, and TG) in children [27] and the latest study by Dahl and others on 228 children with $\mathrm{SH}$ showed that mild SH in children and adolescents was associated with higher rates of elevated total cholesterol and elevated non-HDL-c [30]. These studies have shown higher non-HDL dyslipidemia parameters in subclinical hypothyroid children while demonstrating no significant difference in HDL dyslipidemias between euthyroid and SH groups. Meanwhile, studies by Cerbone et al. and Paoli-Valeri et al. demonstrated the exact opposite. Cerbone and others showed that TG to HDL-C ratio $(P=0.01)$, and HDL-c were significantly lower $(P=0.003)$ in patients with SH compared with controls [28] and in the study by Paoli-Valeri and colleagues on

Table 4 Distribution of lipid profile abnormality based on thyroid status and age

\begin{tabular}{|c|c|c|c|c|c|c|c|c|c|}
\hline & \multicolumn{2}{|l|}{ Total (847) } & \multirow[b]{2}{*}{$P$} & \multicolumn{2}{|c|}{ Age 2-10 (421) } & \multirow[b]{2}{*}{$P$} & \multicolumn{2}{|c|}{ Age 10-18 (426) } & \multirow[b]{2}{*}{$P$} \\
\hline & $\begin{array}{l}\text { Euthyroid } \\
\text { (689) }\end{array}$ & $\begin{array}{l}\text { Subclinical } \\
\text { Hypothyroid (184) }\end{array}$ & & $\begin{array}{l}\text { Euthyroid } \\
\text { (338) }\end{array}$ & $\begin{array}{l}\text { Subclinical } \\
\text { Hypothyroid (100) }\end{array}$ & & $\begin{array}{l}\text { Euthyroid } \\
\text { (351) }\end{array}$ & $\begin{array}{l}\text { Subclinical } \\
\text { Hypothyroid (84) }\end{array}$ & \\
\hline \multicolumn{10}{|l|}{$\overline{\mathrm{TC}}(\mathrm{mg} / \mathrm{dL})$} \\
\hline Acceptable $(<170)$ & $66.4 \%$ & $65.7 \%$ & 0.915 & $63.7 \%$ & $65.6 \%$ & 0.933 & $68.9 \%$ & $65.9 \%$ & 0.672 \\
\hline Borderline-high (170-199) & $24.2 \%$ & $23.8 \%$ & & $27.1 \%$ & $26.0 \%$ & & $21.4 \%$ & $21.2 \%$ & \\
\hline High $(>=200)$ & $9.5 \%$ & $10.5 \%$ & & $9.2 \%$ & $8.3 \%$ & & $9.7 \%$ & $12.9 \%$ & \\
\hline \multicolumn{10}{|l|}{ LDL-c (mg/dL) } \\
\hline Acceptable $(<110)$ & $81.2 \%$ & $83.4 \%$ & 0.682 & $77.8 \%$ & $85.4 \%$ & 0.268 & $84.5 \%$ & $81.2 \%$ & 0.636 \\
\hline Borderline-high (110-129) & $12.3 \%$ & $9.9 \%$ & & $14.8 \%$ & $9.4 \%$ & & $10.0 \%$ & $10.6 \%$ & \\
\hline High $(>=130)$ & $6.5 \%$ & $6.6 \%$ & & $7.4 \%$ & $5.2 \%$ & & $5.6 \%$ & $8.2 \%$ & \\
\hline \multicolumn{10}{|l|}{$\mathrm{HDL}-\mathrm{c}(\mathrm{mg} / \mathrm{dL})$} \\
\hline Acceptable (> 45) & $56.9 \%$ & $61.9 \%$ & 0.266 & $58.8 \%$ & $63.5 \%$ & 0.205 & $55.1 \%$ & $60.0 \%$ & 0.720 \\
\hline Borderline-low (40-45) & $19.8 \%$ & $20.4 \%$ & & $17.2 \%$ & $20.8 \%$ & & $22.3 \%$ & $20.0 \%$ & \\
\hline $\operatorname{Low}(<40)$ & $23.3 \%$ & $17.7 \%$ & & $24.0 \%$ & $15.6 \%$ & & $22.6 \%$ & $20.0 \%$ & \\
\hline \multicolumn{10}{|l|}{ Non-HDL-c (mg/dL) } \\
\hline Acceptable $(<120)$ & $64.0 \%$ & $62.4 \%$ & 0.661 & $64.6 \%$ & $63.5 \%$ & 0.857 & $63.3 \%$ & $61.2 \%$ & 0.213 \\
\hline Borderline-high (120-144) & $24.2 \%$ & $23.2 \%$ & & $21.5 \%$ & $24.0 \%$ & & $26.7 \%$ & $22.4 \%$ & \\
\hline $\operatorname{High}(>=145)$ & $11.9 \%$ & $14.4 \%$ & & $13.8 \%$ & $12.5 \%$ & & $10.0 \%$ & $16.5 \%$ & \\
\hline \multicolumn{10}{|l|}{ TG (mg/dL) } \\
\hline Acceptable $(<75 / 90)$ & $41.0 \%$ & $44.2 \%$ & 0.522 & $38.2 \%$ & $39.6 \%$ & 0.967 & $43.7 \%$ & $49.4 \%$ & 0.400 \\
\hline Borderline-high (75-99/90-129) & $26.7 \%$ & $22.7 \%$ & & $23.7 \%$ & $22.9 \%$ & & $29.6 \%$ & $22.4 \%$ & \\
\hline High ( $>=100 / 130)$ & $32.3 \%$ & $33.1 \%$ & & $38.2 \%$ & $37.5 \%$ & & $26.7 \%$ & $28.2 \%$ & \\
\hline
\end{tabular}


Table 5 Correlation of lipid profile components with serum TSH levels

\begin{tabular}{lll}
\hline Lipid Profile components & Correlation coefficient $(r)$ & $P$ value \\
\hline TC & 0.033 & 0.331 \\
LDL-C & 0.015 & 0.657 \\
HDL-C & 0.039 & 0.257 \\
Non-HDL-C & 0.020 & 0.554 \\
TG & 0.019 & 0.584 \\
\hline
\end{tabular}

Notes: Data are given in $r$ and $P$ values. Correlation coefficient was assessed by partial correlation method. Adjusted for age, sex, and BMI Z-score

Abbreviations: TC total cholesterol; $L D L-c$ low-density lipoprotein cholesterol; $H D L-c$ high-density lipoprotein cholesterol; Non-HDL-c non-high-density lipoprotein cholesterol; TG triglycerides

17 children with $\mathrm{SH}$, the subjects with $\mathrm{SH}$ had significantly lower HDL-c levels [29]. These studies demonstrated no significant difference in total cholesterol and LDL between SH and euthyroid children.

A third group of studies, including ours, have shown no difference in total cholesterol, LDL-c, HDL-c or nonHDL-c between SH and euthyroid children. Çatlı et al., in a study on 27 children with SH compared with a control group, showed that there were similar serum lipoprotein levels and dyslipidemia frequency between the two groups [36] and the study by Nader and co-workers on 131 euthyroid children also found similar results, although a mild relation between TG and TSH was exhibited [31].

Further inspection of the studies for an explanation of the aforementioned differences did not yield results. We hypothesized several factors affecting the results including different dyslipidemia cut off levels, fasting state and the time span of subject inclusion. However none could clarify the differences. For example, while studies by Unal E and Nader NS were conducted in a fasting state, our study and Dahl AR were in a non-fasting state. However, these aforementioned studies had very different results. Another example is that our study and the studies by Paoli-Valeri et al. and Nader NS et al. were conducted on subjects from relatively short time spans while studies by Witte $\mathrm{T}$ and Dahl AR were on subjects from a longer time period. The studies on short time spans had different results while the ones on longer time periods were relatively similar. Regarding the different dyslipidemia cut offs, we noticed that despite the difference in normal lipid profile ranges of each study, the results were mostly obtained from differences in mean serum lipid levels, thus the different cut offs did not affect the primary results.

The question of whether $\mathrm{SH}$ can affect serum lipid levels is very important in preventing atherosclerosis in later years as studies have shown that atherosclerosis often begins in childhood with pediatric dyslipidemia a significant contributing factor [37]. Unlike $\mathrm{SH}$, the association of overt hypothyroidism and dyslipidemia has been more consistent. Although levothyroxine (LT4) treatment exerts some beneficial effects, there is no available data regarding the impact of therapy on metabolic outcomes in children with $\mathrm{SH}[28,36]$. The mechanism of the effect of thyroid hormones on lipid profile is not completely understood. However, thyroid hormones can reduce apoB lipoproteins via a non-LDL receptor pathway that leads to decreased liver apoB production [38]. It is also generally believed that thyroid hormones and their synthetic derivatives known as thyromimetics, can reduce serum cholesterol by their ability to increase LDL receptors, as demonstrated by a recent study illustrating that thyroid hormones and thyroid hormone receptor- $\beta$ selective agonists, GC- 1 and KB2115, were able to reduce serum cholesterol by inducing Cyp7a1 expression and stimulating the conversion and excretion of cholesterol as bile acids [39].

The advantage of our study over other studies is that a large number of children with $\mathrm{SH}$ were included, and also this was a cross-sectional study, while most of the other studies on the relation of TSH and serum lipid concentration are case-control studies spanning several years. A limitation of the study includes not recording serum Anti-TPO levels. Although serum Anti-TPO antibodies are not required for diagnosis of $\mathrm{SH}$, they are recommended for considering therapeutic management of the disease and they would have certainly helped in better analysis of subjects. Precise subject puberty status was also not recorded.

\section{Conclusions}

Based on the results of our study, we found no correlation between $\mathrm{SH}$ and dyslipidemia in children. The association between dyslipidemia and $\mathrm{SH}$ in children still seems to be inconsistent based on the results of this and previous studies. We recommend a meta-analysis or a significantly larger retrospective study on this subject.

\section{Abbreviations \\ TC: Total cholesterol; LDL-C: Low-density lipoprotein cholesterol; HDL- C: High-density lipoprotein cholesterol; Non-HDL-C: Non-high-density lipoprotein cholesterol; TG: Triglycerides; BMI: Body mass index; TSH: Thyroid stimulating hormone; FT4: Free T4; Cl: Confidence interval; CDC: Center for disease control and prevention}

\section{Acknowledgements}

The authors are grateful to individuals who participated in this survey and to Boghrat Laboratory for assisting in biochemical tests. Special thanks to our dear colleagues Dr. Zinatosadat Hejrati and Dr. Zahra Kheirandish for making this study possible.

\section{Authors' contributions}

AshH: Collected the data, performed data analysis, interpreted the data, and wrote the manuscript. AsaH: Designed the study, involved in critical revision of the manuscript. All authors read and approved the final version of the manuscript. 


\section{Funding}

No external funding was provided. The work was conducted by authors as part of their regular duties or on a volunteer basis.

\section{Availability of data and materials}

The datasets used during the current study are available through the corresponding author on reasonable request and upon permission from the university and the clinic.

\section{Ethics approval and consent to participate}

Signed informed consent was obtained from all participants' parents or legal guardians. The study was approved by the Research Institutional Review Committee of Islamic Azad University, Kazerun branch (reference 1398.125). Data for this study were collected retrospectively.

\section{Consent for publication}

Not applicable.

\section{Competing interests}

The authors declare that they have no competing interests.

\section{Author details}

'School of Medicine, Shiraz University of Medical Sciences, Shiraz, Iran. ${ }^{2}$ Department of Endocrinology, School of Medicine, Kazerun Branch, Islamic Azad University, PO Box: 71384-37984, First Floor, Zafar Building, Zand St, Shiraz, Iran.

Received: 2 November 2019 Accepted: 24 August 2020

\section{Published online: 16 September 2020}

\section{References}

1. - Salerno M, Capalbo D, Cerbone M, De luca F. Subclinical hypothyroidism in childhood - current knowledge and open issues. Nat Rev Endocrinol. 2016; 12(12):734-46

2. -Ross DS. Subclinical hypothyroidism in nonpregnant adults. www.uptodate com/contents/subclinical-hypothyroidism-in-nonpregnant-adults. Accessed May 21, 2020

3. -Biondi B, Cooper DS. The clinical significance of subclinical thyroid dysfunction. Endocr Rev. 2008;29(1):76-131.

4. -Paoli-valeri M, Mamán-alvarado D, Jiménez-lópez V, Arias-ferreira A, Bianchi G, Arata-bellabarba G. [Frequency of subclinical hypothyroidism among healthy children and those with neurological conditions in the state of Mérida, Venezuela]. Invest Clin. 2003;44(3):209-18.

5. -Khandelwal D, Tandon N. Overt and subclinical hypothyroidism: who to treat and how. Drugs. 2012;72(1):17-33.

6. -Mcquade C, Skugor M, Brennan DM, Hoar B, Stevenson C, Hoogwerf BJ. Hypothyroidism and moderate subclinical hypothyroidism are associated with increased all-cause mortality independent of coronary heart disease risk factors: a PreCIS database study. Thyroid. 2011;21(8):837-43.

7. -Lervasi G, Molinaro S, Landi P, et al. Association between increased mortality and mild thyroid dysfunction in cardiac patients. Arch Intern Med. 2007;167(14):1526-32.

8. -Floriani C, Gencer B, Collet TH, Rodondi N. Subclinical thyroid dysfunction and cardiovascular diseases: 2016 update. Eur Heart J. 2018;39(7):503-7.

9. -Arem R, Rokey R, Kiefe C, Escalante DA, Rodriguez A. Cardiac systolic and diastolic function at rest and exercise in subclinical hypothyroidism: effect of thyroid hormone therapy. Thyroid. 1996;6(5):397-402.

10. -Arinc H, Gunduz H, Tamer A, Seyfeli E, Kanat M, Ozhan H, Akdemir R, Uyan C. Tissue Doppler echocardiography in evaluation of cardiac effects of subclinical hypothyroidism. Int J Cardiovasc Imaging. 2006;22:177-86. Epub 2005 Nov 2.

11. -Chen X, Zhang N, Cai Y, Shi J. Evaluation of left ventricular diastolic function using tissue Doppler echocardiography and conventional doppler echocardiography in patients with subclinical hypothyroidism aged $<60$ years: a meta-analysis. J Cardiol. 2013;61:8-15. Epub 2012 Oct 18.

12. -Ochs N, Auer R, Bauer DC, et al. Meta-analysis: subclinical thyroid dysfunction and the risk for coronary heart disease and mortality. Ann Intern Med. 2008;148(11):832-45.

13. -Wu T, Flowers JW, Tudiver F, Wilson JL, Punyasavatsut N. Subclinical thyroid disorders and cognitive performance among adolescents in the United States. BMC Pediatr. 2006;6:12.
14. - Monzani F, Caraccio N, Siciliano G, Manca L, Murri L, Ferrannini E. Clinical and biochemical features of muscle dysfunction in subclinical hypothyroidism. J Clin Endocrinol Metab. 1997;82:3315-8.

15. -Loh HH, Lim LL, Yee A, Loh HS. Association between subclinical hypothyroidism and depression: an updated systematic review and metaanalysis. BMC Psychiatry. 2019:19(1):12.

16. -Javed Z, Sathyapalan T. Levothyroxine treatment of mild subclinical hypothyroidism: a review of potential risks and benefits. Ther Adv Endocrinol Metab. 2016;7(1):12-23.

17. -Marras V, Casini MR, Pilia S, et al. Thyroid function in obese children and adolescents. Horm Res Paediatr. 2010;73(3):193-7.

18. -Ghergherehchi R, Hazhir N. Thyroid hormonal status among children with obesity. Ther Adv Endocrinol Metab. 2015;6(2):51-5.

19. -Sami A, Iftekhar MF, Rauf MA, Sher A. Subclinical Hypothyroidism among local adult obese population. Pak J Med Sci. 2018;34(4):980-3.

20. -Reinehr T. Thyroid function in the nutritionally obese child and adolescent. Curr Opin Pediatr. 2011:23(4):415-20.

21. -Reinehr T, De sousa G, Andler W. Hyperthyrotropinemia in obese children is reversible after weight loss and is not related to lipids. J Clin Endocrino Metab. 2006;91(8):3088-91.

22. -Ahi S, Amouzegar A, Gharibzadeh S, Delshad H, Tohidi M, Azizi F. Trend of lipid and thyroid function tests in adults without overt thyroid diseases: A cohort from Tehran thyroid study. PLoS ONE. 2019;14(5):e0216389.

23. -Asvold BO, Vatten $L$, Nilsen TI, Bjøro T. The association between TSH within the reference range and serum lipid concentrations in a populationbased study. The HUNT Study. Eur J Endocrinol. 2007;156(2):181-6.

24. -Rastgooye haghi A, Solhjoo M, Tavakoli MH. Correlation Between Subclinical Hypothyroidism and Dyslipidemia. Iran J Pathol. 2017;12(2):106-11.

25. - Meisinger $C$, Ittermann T, Tiller $D$, et al. Sex-specific associations between thyrotropin and serum lipid profiles. Thyroid. 2014:24:424-32.

26. -Unal E, Akın A, Yıldırım R, Demir V, Yildiz I, Haspolat YK. Association of Subclinical Hypothyroidism with Dyslipidemia and Increased Carotid IntimaMedia Thickness in Children. J Clin Res Pediatr Endocrinol. 2017;9(2):144-9.

27. -Witte T, Ittermann T, Thamm M, Riblet NB, Völzke H. Association between serum thyroid-stimulating hormone levels and serum lipids in children and adolescents: a population-based study of german youth. J Clin Endocrinol Metab. 2015;100(5):2090-7

28. -Cerbone M, Capalbo D, Wasniewska M, et al. Cardiovascular risk factors in children with long-standing untreated idiopathic subclinical hypothyroidism. J Clin Endocrinol Metab. 2014:99(8):2697-703.

29. -Paoli-valeri M, Guzmán M, Jiménez-lópez V, Arias-ferreira A, Briceñofernández M. Arata-bellabarba G. [Atherogenic lipid profile in children with subclinical hypothyroidism]. An Pediatr (Barc). 2005;62(2):128-34.

30. -Dahl AR, labal AM, Lteif AN, Pittock ST, Tebben PJ, Kumar S. Mild subclinical hypothyroidism is associated with paediatric dyslipidaemia. Clin Endocrinol (Oxf). 2018;89(3):330-5.

31. -Nader NS, Bahn RS, Johnson MD, Weaver AL, Singh R, Kumar S Relationships between thyroid function and lipid status or insulin resistance in a pediatric population. Thyroid: official journal of the American Thyroid Association. 2010;20(12):1333-9.

32. -Nordestgaard BG, et al. Fasting is not routinely required for determination of a lipid profile: clinical and laboratory implications including flagging at desirable concentration cut-points - a joint consensus statement from the European Atherosclerosis Society and European Federation of Clinical Chemistry and Laboratory Medicine. Eur Heart J. 2016:37:1944-58.

33. -Lazarus J, Brown RS, Daumerie C, Hubalewska-dydejczyk A, Negro R, Vaidya B. 2014 European thyroid association guidelines for the management of subclinical hypothyroidism in pregnancy and in children. Eur Thyroid J. 2014;3(2):76-94

34. - Expert Panel on Integrated Guidelines for Cardiovascular Health. and Risk Reduction in Children and Adolescents, National Heart, Lung, and Blood Institute. Expert panel on integrated quidelines for cardiovascular health and risk reduction in children and adolescents: summary report. Pediatrics. 2011:128(Suppl 5):213.

35. -Dai S, Yang Q, Yuan K, et al. Non-high-density lipoprotein cholesterol: distribution and prevalence of high serum levels in children and adolescents: United States National Health and Nutrition Examination Surveys, 2005-2010. J Pediatr. 2014:164:247.

36. -Çatlı G, Anık A, Ünver tuhan H, Böber E, Abacı A. The effect of L-thyroxine treatment on hypothyroid symptom scores and lipid profile in children with subclinical hypothyroidism. J Clin Res Pediatr Endocrinol. 2014;6(4):238-44. 
37. -Webber LS, Srinivasan SR, Wattigney WA, Berenson GS. Tracking of serum lipids and lipoproteins from childhood to adulthood. The Bogalusa Heart Study. Am J Epidemiol. 1991;133(9):884-99.

38. -Goldberg IJ, Huang LS, Huggins LA, et al. Thyroid hormone reduces cholesterol via a non-LDL receptor-mediated pathway. Endocrinology. 2012; 153(11):5143-9.

39. -Lin JZ, Martagón AJ, Hsueh WA, et al. Thyroid hormone receptor agonists reduce serum cholesterol independent of the LDL receptor. Endocrinology. 2012;153(12):6136-44.

\section{Publisher's Note}

Springer Nature remains neutral with regard to jurisdictional claims in published maps and institutional affiliations.

Ready to submit your research? Choose BMC and benefit from:

- fast, convenient online submission

- thorough peer review by experienced researchers in your field

- rapid publication on acceptance

- support for research data, including large and complex data types

- gold Open Access which fosters wider collaboration and increased citations

- maximum visibility for your research: over $100 \mathrm{M}$ website views per year

At BMC, research is always in progress.

Learn more biomedcentral.com/submissions 